\title{
Evaluation of Native Rooster Based on Breeding Value of trait of Macroscopic and Microscopic Semen Quality
}

\author{
Sutiyono, E. Kurnianto, Sutopo, D. K. Ariyanto, and D. Samsudewa \\ Department of Animal Science, Faculty of Animal and Agricultural Sciences, Universitas Diponegoro \\ Corresponding Author: daudreproduksi@gmail.com
}

\begin{abstract}
The aim of this research is to a determined the breeding value of native roosters based on macroscopic and microscopic semen. Ten native roosters were used in this research. Complete individual cage, semen collection tools and substance, macroscopic and microscopic tools, and substance were used in this research. The native rooster was rested for 2 weeks. Massage techniques were used for semen collection. Parameters observed were volume, $\mathrm{pH}$, color, viscosity, smell, sperm concentration, and sperm livability. The semen collection was repeated 5 times. One-way analysis of variances was used for data analysis with the tools SPSS 16. The breeding value was estimated based on primary traits of semen and calculated for each rooster to make a rank. The results showed that significant parameters $(\mathrm{P}<0,05)$ are semen volume and sperm concentration, while the non-significant parameters $(\mathrm{P} \geq 0,05)$ are $\mathrm{pH}$ semen and sperm livability. Semen color is yellowish-white, semen viscosity is medium-viscous and smell is spermin. The results of breeding value rank are rooster numbers $6,7,5,3,2,4,8$, 9,10 , and 1 . The conclusion is the breeding value of Native roosters is varied. The recommendation is Native chicken breeding need to apply selection used breeding value based on semen quality.
\end{abstract}

Key words: Native rooster evaluation, breeding value, semen quality

\section{INTRODUCTION}

Native chicken is one of the subspecies of Gallus sp that widespread in Indonesia. The community in Indonesia was eating native chicken because of flavored meat and they believe that it healthier compare with broiler chicken. This is connected with the usage of antibiotics during the nourishment of broiler. That is the reason why native chickens have been nourished in all parts of Indonesia.

Breeding Value is the knowledge of genetic to improve the primary trait as well as other traits that are connected with economic value (Rajkumar et al., 2021). The expectation from breeding value estimation is to choose the best parental. Breeding value estimation can be applied to all livestock including cows, buffalo, goats, sheep, and chickens.

Breeding value can be applied in productive and reproduction traits. Growth analysis, egg weight, and egg production are some of the production traits in Red Dahlem chicken that can be estimated as breeding values (Rajkumar et al., 2021). Some primary reproduction traits for native roosters in Nigeria are macroscopic (semen volume and color) and microscopic (sperm concentration, motility, and morphology) (Usman et al., 2021). Semen quality, fertility, and hatchability of eggs are some parameters that are measured as reproductive traits in Fars indigenous chicken (Mohammadifar and Mohammadabadi, 2017).

Breeding value was also estimated in native roosters in Indonesia on motility, mass movement, and abnormality (Zen et al., 2020). Moreover, some parameters have a higher level of breeding value in native roosters based on microscopic semen evaluation (Junaedi et al., 2016). The parameters are sperm concentration and sperm livability. Therefore, this research will determine breeding value based on macroscopic and microscopic semen (sperm concentration and sperm livability).

\section{MATERIALS AND METHODS}

Ten native roosters with an average body weight of $2.65 \pm 0.39 \mathrm{~kg}$, big red perch and have a spur was used in this research. Individual cage, feeder tray, drinking jar, spuit $1 \mathrm{ml}$, Eppendorf tube, $\mathrm{pH}$ universal indicator, beaker glass, Haemocytometer pipet, pipet, object-glass, cover glass, hand tally counter, sodium chloride $0.9 \%$, Neubauer chamber, eosin $2 \%$, tissue, and microscope were used in this research. Native roosters were rested for 2 weeks in an individual cage before semen collection for environmental adaptation. Massage techniques were used for semen collection. The semen collection was repeated 5 times with 2 days paused. 
Parameters observed were volume, $\mathrm{pH}$, color, viscosity, smell, sperm concentration, and sperm livability. Eppendorf tube was used for collecting and measuring the volume of semen. a $\mathrm{pH}$ of semen was measured used $\mathrm{pH}$ universal indicator range 6-8 with a sensitivity of 0.3 . The color of semen was differentiated by white, yellowish-white, and yellow. Viscosity was carried out by tilted the Eppendorf tube and differentiated into the liquid, medium and viscous. The smell was differentiated by spermin or stinky. Sperm concentration was counted used the Neubauer chamber and Haemocytometer pipet. Semen was filled to the hemocytometer pipet up to 0.5 and after that filled by eosin $2 \%$ up to 1.01 . The hemocytometer was shaking for 2-3 minutes. Two drops of the solution were dripped to the tissue after that drips the solution to the Nabeur chamber covered with cover glass. Count the number of sperm in 80 squares of Nabeur chamber and times by $10^{7}$. Livability was counted by drips the semen to the object-glass covered by a cover glass. Ten fields of view were observed about sperm motility. Sperm motility was observed every 10 minutes up to un-qualified for artificial insemination ( $40 \%$ sperm motility). Minutes used as the unit.

One-way analysis of variances was used for data analysis with the tools SPSS 16. The breeding value was estimated based on primary traits of semen and calculated for each rooster to make a rank. Native rooster's breeding value rank based on the most to less important parameter related to fertilization. The scoring method was used is:

1. Livability, the most important parameter related with fertilization related with longer time

2. at room temperature. The livability optimum of native rooster sperm is 60 minutes (Wiyanti et al., 2013). Scoring of breeding value is 5 stratification $(9,8,7$, $6,5)$ based on the reference.

3. Sperm concentration is the second level of parameters. The difference between the highest and lowest average was counted. Six stratifications were used in these parameters $(8,7,6,5,4,3)$.

4. Volume is the third level of parameters. The difference between the highest and lowest average was counted. Five stratifications were used in these parameters $(7,6,5,4,3)$.

5. $\mathrm{pH}$, is the fourth level of parameters. The optimum $\mathrm{pH}$ is 7.0-7.5 (Mavi et al., 2019). Scoring was divided by 3 stratified $(4=\mathrm{pH} 7.0-7.5 ; 2=\mathrm{pH} 6,5-$ 7,0 or $7.5-8.0$ and $0=<6.5$ or $>8.0$ ).

6. Viscosity is the fifth level of parameters. Scoring was divided by 3 stratified (3= viscous; $2=$ medium and $1=$ liquid).

7. Color is also the fifth level of parameters. Scoring was divided by 3 stratified $(3=$ yellowish-white; 2 = Milky white and $0=$ clear .

8. The smell is the sixth level of the parameter. Scoring was divided by 2 stratified $(1=$ spermin; $0=$ stinky $)$.

\section{RESULTS AND DISCUSSION}

The results of the research about macroscopic semen of Native roosters showed in Table 1 . The results showed that the significantly different $(\mathrm{P}<0,05)$ parameter on macroscopic semen of Native roosters is a volume with an average of $0.16 \pm 0.09-0.72 \pm 0.18 \mathrm{ml}$. Nevertheless, the $\mathrm{pH}$ of Native roosters semen showed a non-significant difference $(\mathrm{P} \geq 0,05)$ with an average of $7.58 \pm 0.50-8.18 \pm 0.33$. Color average is yellowish-white, Viscosity is mediumviscous and smell is spermin.

The volume of semen of Native roosters in this research is in the same range and some roosters were higher compared with the research of Malik et al., (2013). Research about volume semen in red jungle fowl, domestic chicken and bantam chicken is $0.33 \pm 0.16 ; 0.29 \pm 0.18$ and $0.10 \pm 0.10 \mathrm{ml}$, respectively (Malik et al., 2013). $\mathrm{pH}$ semen Native roosters in this research are higher than 7.5. Research on red jungle fowl, domestic chicken and bantam chicken in Malaysia showed the $\mathrm{pH}$ of semen is 7.0-7.5 (Malik et al., 2013). The same $\mathrm{pH}$ semen also showed by the research in a different group of layer chicken (Mavi et al., 2019). The most normal pH in the present study is the highest volume of semen. The condition of higher $\mathrm{pH}$ semen is connected with semen plasma production in the vesicular seminalis gland or the capability of semen to control the $\mathrm{pH}$ semen connected with sperm metabolism. 
Table 1. Macroscopic semen quality of Native rooster

\begin{tabular}{cccccc}
\hline \multirow{2}{*}{ Rooster } & \multicolumn{5}{c}{ Macroscopic Semen Quality } \\
\cline { 2 - 6 } & Volume $(\mathrm{ml})$ & Smell & Viscosity & Color & $\mathrm{pH}$ \\
\hline 1 & $0.30 \pm 0.16^{\mathrm{ab}}$ & Spermin & Viscous & Yellowish white & $8.12 \pm 0.23^{\mathrm{a}}$ \\
2 & $0.42 \pm 0.19^{\mathrm{abc}}$ & Spermin & Viscous & Yellowish white & $7.92 \pm 0.30^{\mathrm{a}}$ \\
3 & $0.42 \pm 0.11^{\mathrm{abc}}$ & Spermin & Medium & Yellowish white & $7.74 \pm 0.36^{\mathrm{a}}$ \\
4 & $0.50 \pm 0.12^{\mathrm{bc}}$ & Spermin & Medium & Yellowish white & $7.66 \pm 0.46^{\mathrm{a}}$ \\
5 & $0.72 \pm 0.18^{\mathrm{c}}$ & Spermin & Medium & Yellowish white & $7.58 \pm 0.50^{\mathrm{a}}$ \\
6 & $0.20 \pm 0.10^{\mathrm{ab}}$ & Spermin & Viscous & Yellowish white & $7.72 \pm 0.53^{\mathrm{a}}$ \\
7 & $0.34 \pm 0.19^{\mathrm{ab}}$ & Spermin & Viscous & Yellowish white & $7.68 \pm 0.44^{\mathrm{a}}$ \\
8 & $0.40 \pm 0.16^{\mathrm{ab}}$ & Spermin & Viscous & Yellowish white & $7.74 \pm 0.35^{\mathrm{a}}$ \\
9 & $0.16 \pm 0.09^{\mathrm{a}}$ & Spermin & Viscous & Yellowish white & $7.84 \pm 0.41^{\mathrm{a}}$ \\
10 & $0.28 \pm 0.16^{\mathrm{ab}}$ & Spermin & Viscous & Yellowish white & $8.18 \pm 0.33^{\mathrm{a}}$ \\
\hline
\end{tabular}

a, b, c different superscript alphabet showed a significant difference on level 5\%

The results of the research about microscopic semen of Native roosters showed in Table 2. The results showed that the significant difference $(\mathrm{P}<0,05)$ parameter on microscopic semen of Native rooster is sperm concentration with an average of $267.80 \pm 79.77 \times 10^{7} \mathrm{cell} / \mathrm{ml}-$ $498.13 \pm 35.13 \times 10^{7}$ cell $/ \mathrm{ml}$. Moreover, the livability of Native roosters semen showed a nonsignificant difference $(\mathrm{P} \geq 0,05)$ with an average of $111 \pm 39.52$ minutes $-164 \pm 51.30$ minutes.

The sperm concentration of Native roosters in the present study is mostly higher than research in different groups genetic of a layer in India $\left(182.6 \pm 7.76 \times 10^{7} 10^{7} \mathrm{cell} / \mathrm{ml}-280.4 \pm\right.$ $11.510^{7} \mathrm{cell} / \mathrm{ml}$ ) (Mavi, et al., 2013). The research of Native roosters in Indonesia is also lower than the present study $\left(313.0 \pm 29.3 \times 10^{7} 10^{7} \mathrm{cell} / \mathrm{ml}\right)$.
The livability in the present study is higher compare with some other research. Research in Native roosters used room temperature in Aceh, Indonesia showed that the motility of sperm before 60 minutes is $10.42 \pm 4.82$ minutes (Lubis, 2011). The livability of two local chickens on Egypt National Gene Bank and Genetic Resources in room temperature after cryopreservation showed livability $59.26 \pm 0.67$ and $54.55 \pm 0.96$ minutes, respectively (Roushdy et al., 2014). In present study showed that the native rooster has higher sperm concentration and livability. Moreover, the present study will choose the best native rooster for natural and artificial mating. Breeding value is needed to determine the best native rooster.

Table 2. Concentration and livability of sperm Native rooster

\begin{tabular}{ccc}
\hline \multirow{2}{*}{ Rooster } & \multicolumn{2}{c}{ Concentration and livability of sperm } \\
\cline { 2 - 3 } & Concentration (x 10 $0^{7}$ sperm/ml) & Livability (minutes) \\
\hline 1 & $267.80 \pm 79,77^{\mathrm{ab}}$ & $132 \pm 26.07^{\mathrm{a}}$ \\
2 & $293.20 \pm 51.76^{\mathrm{ab}}$ & $164 \pm 51.30^{\mathrm{a}}$ \\
3 & $341.60 \pm 32.30^{\mathrm{bc}}$ & $123 \pm 24.62^{\mathrm{a}}$ \\
4 & $208.53 \pm 35.90^{\mathrm{a}}$ & $114 \pm 40.52^{\mathrm{a}}$ \\
5 & $300.66 \pm 42.31^{\mathrm{ab}}$ & $120 \pm 28.06^{\mathrm{a}}$ \\
6 & $498.13 \pm 35.13^{\mathrm{d}}$ & $111 \pm 39.52^{\mathrm{a}}$ \\
7 & $494.26 \pm 53.13^{\mathrm{cd}}$ & $135 \pm 50.63^{\mathrm{a}}$ \\
8 & $289.93 \pm 53.13^{\mathrm{cd}}$ & $125 \pm 23.18^{\mathrm{a}}$ \\
9 & $310.73 \pm 46.39^{\mathrm{ab}}$ & $120 \pm 43.73^{\mathrm{a}}$ \\
10 & $283.86 \pm 20.70^{\mathrm{ab}}$ & $125 \pm 28.93^{\mathrm{a}}$ \\
\hline $\mathrm{a}, \mathrm{b}, \mathrm{c}$ & different superscript alphabet showed a significant difference on level $5 \%$.
\end{tabular}

The results about the breeding value of Native roosters showed in Table 3 . The breeding value score of Native roosters is number 6 (score
30), number 7 (score 29), number 3 and 5 (score 28), number 2 (score 27), number 4, 8, 9 (score 26) and number 1 and 10 (score 24). 
Table 3. Breeding value score of Native roosters

\begin{tabular}{lcccccccccc}
\hline \multirow{1}{*}{ Parameters } & \multicolumn{10}{c}{ Native Roosters Number } \\
\cline { 2 - 11 } & 1 & 2 & 3 & 4 & 5 & 6 & 7 & 8 & 9 & 10 \\
\hline Livability & 9 & 9 & 9 & 9 & 9 & 9 & 9 & 9 & 9 & 9 \\
Concentration & 4 & 4 & 6 & 3 & 4 & 8 & 7 & 4 & 5 & 4 \\
Volume & 4 & 5 & 5 & 6 & 7 & 4 & 4 & 4 & 3 & 4 \\
pH & 0 & 2 & 2 & 2 & 2 & 2 & 2 & 2 & 2 & 0 \\
Viscosity & 3 & 3 & 2 & 2 & 2 & 3 & 3 & 3 & 3 & 3 \\
Color & 3 & 3 & 3 & 3 & 3 & 3 & 3 & 3 & 3 & 3 \\
Smell & 1 & 1 & 1 & 1 & 1 & 1 & 1 & 1 & 1 & 1 \\
\hline Breeding Value Score & 24 & 27 & 28 & 26 & 28 & 30 & 29 & 26 & 26 & 24 \\
\hline
\end{tabular}

The present study showed that the best native rooster is numbers $6,7,3$, and 5 . Breeding value is important for the conservation of local genetic (Roushdy et al., 2014). Breeding value is controlled by a gene in all animals including Native roosters. Moazeni et al., (2016), stated that breeding value in reproduction traits in Mazandaran indigenous chicken is control by uncoupling protein 3 (UCP3). The developed method for estimated breeding value is combined pedigree and genomic covariance matrix (Wolc et al., 2011). The present study will follow with further research about growth analysis of tiller used natural or artificial mating. This further research will show the real breeding value.

\section{CONCLUSION}

The conclusion is the breeding value of Native roosters is varied. The Native chicken breeding needs to apply selection used breeding value based on semen quality and followed by pedigree.

\section{ACKNOWLEDGMENT}

Thanks to the Rector of Universitas Diponegoro and Dean of the Faculty of Animal and Agricultural Sciences. Through research funding support based on the Decree of Rector Universitas Diponegoro Number: 109/UN7.5.5/PP/2018, this research can be done.

\section{REFERENCES}

Junaedi, R. I. Arifiantini, C. Sumantri and A. Gunawan. 2016. Use of glycerol as cryoprotectants in freezing Sentul chicken. CJAH 1 (2): 7-13. URL: http://usnsj.com/ index.php/CJAH/article/view/CJAH002.

Lubis, T. M. 2011. Motilitas spermatozoa ayam kampung dalam pengencer air kelapa, $\mathrm{Na}$
$\mathrm{Cl}$ fisiologis dan air kelapa- $\mathrm{NaCl}$ fisiologis pada $25-29^{\circ} \mathrm{C}$. Agripet 11 (2): 45-50, URL: http://www.jurnal.unsyiah.ac.id/agripet/art icle/viewFile/374/359.

Malik, A., A. W. Haron, R. Yussof, M. Nesa, M. Bukar and A. Kasim. 2013. Evaluation of the ejaculate quality of the red jungle fowl, domestic chicken and bantam chicken in Malaysia. Turk. J. Vet. Anim. Sci. 37: 564568. DOI: $10.3906 /$ vet-1107-26.

Mavi, G.K., P. P. Dubey, S. C. Ranjna, S. K. Dash and B, K, Bansal. 2019. Comparative analysis of semen quality parameters and their relationship with fertility in different genetic groups of layer chicken. Indian Journal of Animal Research 53 (10): 12691274. DOI: 10.18805/ijar.B-3646.

Moazeni, S. M., M. Mohammadabadi, M. Sadeghi, H. M. Shahrbabak, A. E. Koshkoieh and F. Bordbar. 2016. Association between UCP gene polymorphisms and growth, breeding value of growth and reproductive traits in Mazandaran indigenous chicken. Open Journal of Animal Sciences 6: 1-8. DOI: $10.4236 /$ ojas.2016.61001.

Mohammadifar, A. and M.R. Mohammadabadi. 2017. The effect of uncopling protein polymorphisms on growth, breeding value of growth and reproductivo traits in the Fars indigenous chicken. IJAS 7 (4): 679-685. URL:

http://ijas.iaurasht.ac.ir/article_535799 .html.

Rajkumar, U., L. L. L. Prince, K. S. Rajaravindra, S. Haunshi, M. Niranjan and R. N. 
Chatterjee. 2021. Analysis of (co) variance components and estimation of breeding value of growth and production traits in Dahlem Red chicken using pedigree relationship in an animal model. PloS ONE 16 (3): 1-21. DOI: https://doi.org/10.1371/journal.pone. 0247779.

Roushdy, Kh., M. A. El-Sherbieny, F. A. Abd. El Gany and M. A. El-Sayed. 2014. Semen cryopreservation for two local chicken strains as a tool for conservation of Egyptian local genetic resources. EPSA 34 (II): 607-618.

URL: https://www.researchgate.net/ publication/277308492_Semen_cryopreser vation_for_two_local_chicken_Strains_as _a_tool_for_conservation_of_Egyptian_lo cal_genetic_resources

Usman, T. H., S. M. Sir, S. Halu and A. Kari. 2021. Assessment of semen characteristics among three phenotypes of chicken raised in Akko, Gombe state of Nigeria. Jornal of Agrobiotechnology 12 (1): 40-48.. DOI: http://dx.doi.org/10.37231/jab.2021.12.1.2 42.
Wiyanti, D. C., N. Isnaini and P. Trisunuwati. 2013. Effect of semen storage added with physiological saline diluter in room temperature on the quality of native chicken (gallus domesticus) spermatozoa. J. Kedokt. Hewan 7 (1): 53-55. DOI: https://doi.org/10.21157/ j.ked.hewan.v7i1.566.

Wolc, A., C. Stricker, J. Arango, P. Settar, J. E. Fulton, N. P. O'Sullivan, R. Preisinger, D. Habier, R. Fernando, D. J. Garrick, S. J. Lamont, J. C. M. Dekkers. 2011. Breeding value prediction for production traits in layer chickens using pedigree or genomic relationships in a reduced animal model. Genetic Selection Evolution 43 (5): 1-9. URL: $\quad$ https://link. springer.com/content/pdf/10.1186/12979686-43-5.pdf.

Zen, A. A., Y. S. Ondho dan Sutiyono. 2020. Seleksi pejantan ayam kampung berdasarkan breeding value terhadap gerak massa, abnormalitas dan motilitas spermatozoa. JSPI 15 (3): 339-347. DOI: https://doi.org/10.31186/jspi.id.15.3.339347. 